\title{
Novel 2,3-disubstituted 1,3-thiazolidin-4-one derivatives as potential antitumor agents in renal cell adenocarcinoma
}

\author{
MONIKA GAWROŃSKA-GRZYWACZ ${ }^{1}$, ŁUKASZ POPIOŁEK ${ }^{2}$, \\ DOROTA NATORSKA-CHOMICKA ${ }^{1}$, IWONA PIĄTKOWSKA-CHMIEL ${ }^{1}$, \\ MAGDALENA IZDEBSKA ${ }^{1}$, MARIOLA HERBET ${ }^{1}$, MAGDALENA IWAN ${ }^{1}$, \\ AGNIESZKA KORGA $^{1}$, JAROSŁAW DUDKA ${ }^{1}$ and MONIKA WUJEC ${ }^{2}$ \\ Departments of ${ }^{1}$ Toxicology and ${ }^{2}$ Organic Chemistry, Faculty of Pharmacy with Medical Analytics Division, \\ Medical University of Lublin, Lublin 20-090, Poland
}

Received February 15, 2018; Accepted October 3, 2018

DOI: 10.3892/or.2018.6800

\begin{abstract}
Cancer represents one of the main causes of mortality in developed countries. In particular, the overall survival of patients with renal cell carcinoma (RCC) remains poor and the available cytostatic agents are insufficient. Therefore, there is an urgent requirement to identify more effective and safer anticancer drugs. Recently, the evaluation of antitumor activity appeared to be promising for thiazolidinone derivatives. The present study presents the synthesis and the cytotoxicity assays of 1,3-thiazolidin-4-ones. The newly synthesized substances were screened in vitro against selected cancer human renal cell adenocarcinoma cells (769-P), human hepatoblastoma-derived cells (HepG2) and normal green monkey kidney cells (GMK) as a reference cell line. $N$-[2-(4-methylphenyl)-4-oxo-1,3-thiazolidin-3-yl]acetamide and $N$-[2-(4-methylphenyl)-4-oxo-1,3-thiazolidin-3-yl] benzamide displayed significant antiproliferative activity towards 769-P. To elucidate the mechanisms of the cytotoxic actions, additional studies on the cell cycle and apoptosis were performed. The aforementioned compounds were responsible for G1 cell cycle arrest and the decrease in cell distribution in the G2 phase in a dose-dependent manner, which prevents mitotic divisions of the 769-P cells. In addition, these novel 2,3-disubstituted 1,3-thiazolidin-4-ones slightly induced apoptosis in 769-P in a dose-dependent manner. It was hypothesized that the 4-methylphenyl group at position 2 of the thiazolidin-4-one scaffold may be regarded as a promising moiety for further development of this group of compounds. Therefore, benzamide moiety appeared to be crucial for triggering cells to apoptotic cell death.
\end{abstract}

Correspondence to: Dr Monika Gawrońska-Grzywacz, Department of Toxicology, Medical University of Lublin, 8b Jaczewski Street, Lublin 20-090, Poland

E-mail: monika.grzywacz@umlub.pl

Key words: 1,3-thiazolidin-4-one derivatives, HepG2, 769-P, MTT assay, cell cycle, apoptosis

\section{Introduction}

Cancer remains the second leading cause of mortality in developed countries, exceeded only by heart disease (1). Liver and kidney cancer are among the top ten most common malignancies worldwide. An increase in the incidence rate has been observed and the two types of cancer have a very high fatality rate (2-8). The incidence of kidney cancer varies geographically: The rates are highest in more developed regions in Europe, North America and Australia and they are lowest in Africa and South-East Asia $(7,8)$. Kidney cancer is more often diagnosed in males globally $(6,7)$. The development of this tumor is dependent on intrinsic (genetic predisposition, sex and age) and extrinsic risk factors (smoking, obesity and alcohol abuse) (8). Hepatoblastoma is the most common liver neoplasm in children that is diagnosed during the early years of life; it is an embryonal malignancy of hepatocellular origin $(3,4,9)$. Therapeutic strategies include surgical resection and chemotherapy $(3,4)$. Although $60 \%$ of tumors are unresectable at presentation, adjuvant chemotherapy effectively reduces tumor size, allowing surgical intervention in the majority of patients (3). However, the prognosis for children with advanced or chemotherapy-refractory cancer remains poor (4). Renal cell carcinoma (RCC) comprises 90\% cases of all kidney cancer. RCC, as the most frequent type of renal neoplasm, is also the most lethal among all urological tumors (8). In 75-80\% cases, RCC can easily invade neighboring tissues and metastasize, and is often resistant to currently available therapeutic strategies. The patients respond poorly to conventional cytostatic drugs and radiotherapy (10). The 5-year survival rates of RCC are estimated at only 50\%; the fact that at first diagnosis $20-30 \%$ of patients have metastatic disease is one of the reasons for this prognosis $(11,12)$. In addition, $>40 \%$ of patients develop metastases following radical nephrectomy (13). However, successful treatment, particularly at metastatic stages, remains a challenge. Overall, metastatic RCC remains incurable, although targeted therapeutic strategies, including mammalian target of rapamycin inhibitors appeared to have improved efficacy (14). Despite recent advances, the outlook for patients remains poor. The search and discovery of novel and safer anticancer agents with 
higher cytotoxicity in cancer cells may aid in improving the management of these types of cancer.

The increasing diversity of small molecule libraries provides an important source for the discovery of novel drug candidates. In this context, heterocycles and in particular 1,3-thiazolidin-4-ones are one of the most extensively investigated classes of compounds. They are heterocyclic nuclei with an atom of sulfur and nitrogen at position 1 and 3, respectively, and a carbonyl group at position 4 . Studies of the synthesis and bioactivity of these derivatives have attracted significant attention $(15,16)$. These derivatives are known to exhibit antimicrobial (17-21), anticonvulsant (22), antihistaminic (23) and cardioprotective (24) bioactivities. In our previous study, the 2,3-disubstituted 1,3-thiazolidin-4-one derivatives were revealed to exhibit significant antimicrobial activity (25). Among twenty compounds tested, particularly $\mathrm{N}$-[2-(4-methylphenyl)-4-oxo-1,3-thiazolidin-3-yl]benzamide possessedaspectrumofbioactivityagainstGram-positivebacteria (staphylococci, streptococci, micrococci and Bacillus spp.). The aforementioned derivative also exhibited activity against yeasts belonging to Candida spp., mainly Candida albicans (25). The 1,3-thiazolidin-4-one derivatives are also known for their anticancer activity $(26,27)$. A review of current literature revealed that 2,5-disubstituted 1,3-thiazolidin-4-ones had been reported for their antiproliferative activity; for example, in human colon adenocarcinoma cells (HT29), human gastric cancer cell line, human colon cancer cell lines and sarcoma-derived cells $(28,29)$. It was reported that 5-benzylidene-4-thiazolidinone derivatives demonstrated significant antitumor potential with various biotargets and mechanisms, including sphingosine kinase (SK), JNK stimulating phosphatase-1 (JSP-1) or non-membrane protein tyrosine phosphatase (SHP-2) (16,30). The 2,3,5-trisubstituted derivatives were demonstrated to induce cell growth arrest in HT29 cells and significant cytotoxicity towards human lung and human breast cancer cultures (31). In turn, 2-phenylimino-3-alkyl-4-thiazolidinone derivatives hindered the proliferation of HT29 cells, characterized by CDK1/cyclin B inhibition. This effect was achieved by blocking cell progression at the G2/M phase border and inducing apoptosis (16). The 2,3-disubstituted 4-thiazolidinone derivatives were also active against leukemia cell lines (26). Due to the aforementioned results, the antiproliferative potential of 1,3-thiazolidin-4-ones, as well as the general cellular mechanisms associated with it, were investigated.

To the best of our knowledge, the present study was the first scientific report of the anticancer potential of 1,3-thiazolidin-4-ones in RCC (769-P). In addition, the impact of other derivatives from this chemical group on HepG2 cells was studied only by George et al (32). The aim of the present study was to synthesize and evaluate the cytotoxicity of the aforementioned $N$-[2-(4-methylphenyl)-4-oxo-1,3-thiazolidin-3-yl] benzamide and three other promising compounds (25) towards these human cancer cell lines. The effects on cell viability were assessed by MTT assay, and the effects on the cell cycle and apoptosis were also investigated. The cell cycle assay has applicability to drug screening, as dysregulation of the cell cycle is a common occurrence in neoplasia, thereby providing the opportunity to discover novel targets for anticancer agents. The Annexin $\mathrm{V}$ assay was also selected as a useful tool in detecting apoptotic cells.

\section{Materials and methods}

Reagents. All required chemicals and solvents were purchased from Sigma-Aldrich; Merck KGaA (Darmstadt, Germany) and Merck KGaA, and were used without further purification. Melting points were determined using Fisher-Johns blocks (Thermo Fisher Scientific, Inc., Waltham, MA, USA) and were uncorrected. The ${ }^{1} \mathrm{HNMR}$ and ${ }^{13} \mathrm{C}$ NMR spectra were recorded on the Bruker Avance 300 apparatus (Bruker Corporation, Ettlingen, Germany) in dimethyl sulfoxide (DMSO) $-\mathrm{d}_{6}$ with tetramethylsilane as the internal standard. The progress of the reaction and the purity of the obtained compounds were monitored by thin-layer chromatography using precoated aluminum sheet $60 \mathrm{~F} 254$ plates (Merck $\mathrm{KGaA}$ ), in a $\mathrm{CHCl}_{3} / \mathrm{C}_{2} \mathrm{H}_{5} \mathrm{OH}$ $(10: 1, \mathrm{v} / \mathrm{v})$ solvent system. The spots were detected by exposure to the UV lamp at $254 \mathrm{~nm}$. The elemental analysis of obtained compounds was performed using the AMZ $851 \mathrm{CHX}$ analyzer (Gdańsk University of Technology, Gdańsk, Poland). The results of elemental analysis $(\mathrm{C}, \mathrm{H}, \mathrm{N})$ were within $\pm 0.4 \%$ of the calculated values.

Preparation of 2,3-disubstituted 1,3-thiazolidin-4-one derivatives (5-8). Synthesis was performed according to procedure described previously by Popiołek et al (25). To the solution of corresponding $N$-substituted hydrazide derivatives (1-4) $(10 \mathrm{mmol})$ in 1,4-dioxane $(15 \mathrm{ml})$, mercaptoacetic acid $(0.92$ $\mathrm{g}, 10 \mathrm{mmol}$ ) was added dropwise. The mixture was stirred for $6 \mathrm{~h}$ at room temperature. Next, the solvent was removed under reduced pressure to obtain a crude product, which was purified by recrystallization from ethanol. The following derivatives were prepared: $N$-[2-(3-nitrophenyl)-4-oxo-1,3thiazolidin-3-yl]acetamide [compound 5; CAS Registry Number: 1644570-76-2; analytical and spectral data are consistent with those reported by Popiołek et al (25); yield, 69\%; meltingpoint(m.p.),was 202-204 $\left.{ }^{\circ} \mathrm{C}\right] ; N$-[2-(4-methylphenyl)4-oxo-1,3-thiazolidin-3-yl]acetamide (compound 6; CAS Registry Number: 1644570-74-0; analytical and spectral data are consistent with those reported by Popiołek et al (25); yield, 81\%; m.p., $104-106^{\circ} \mathrm{C}$ ); $\mathrm{N}$-[2-(3-nitrophenyl)-4-oxo1,3-thiazolidin-3-yl]benzamide (compound 7; CAS Registry Number: 1644570-79-5; analytical and spectral data are consistent with those reported by Popiołek et al (25); yield, $70 \%$; m.p., $176-178^{\circ} \mathrm{C}$ ); and $N$-[2-(4-methylphenyl)4-oxo-1,3-thiazolidin-3-yl]benzamide (compound 8; CAS Registry Number: 1644570-78-4; analytical and spectral data are consistent with those reported by Popiołek et al (25); yield, $87 \%$; m.p., $106-108^{\circ} \mathrm{C}$ ).

Cell culture. The present study used normal green monkey kidney cells (GMK) obtained from Biomed Serum and Vaccine Production Plant Ltd. (Lublin, Poland) and tumor cell cultures supplied by American Type Culture Collection (ATCC; Manassas, VA, USA), including HepG2 (human hepatoblastoma-derived cells; catalog no. HB-8065) and 769-P (human renal cell adenocarcinoma; catalog no. CRL-1933) (9). The GMK cell line was cultured in basic RPMI-1640 medium [with L-glutamine, 4-(2-hydroxethyl)-1-piperazineethanesulfonic acid (HEPES) and sodium decarbonate] and the 769-P cell line was cultured in rich-component RPMI-1640 medium (with L-glutamine, sodium pyruvate, glucose, HEPES and sodium 
dicarbonate). The HepG2 cells were cultured in Eagle's minimal essential medium (EMEM). All the media were supplemented with $10 \%$ fetal bovine serum (FBS), $100 \mathrm{U} / \mathrm{ml}$ penicillin, $100 \mu \mathrm{g} / \mathrm{ml}$ streptomycin and $2.5 \mu \mathrm{g} / \mathrm{ml}$ amphotericin B. The cell cultures were grown in $75 \mathrm{~cm}^{2}$ tissue culture flasks (EasYFlasks ${ }^{\mathrm{TM}}$ Nunclon $^{\mathrm{TM}} \Delta$; Nalge Nunc International, Penfield, NY, USA) as a monolayer in a humidified atmosphere of $5 \% \mathrm{CO}_{2}$ at $37^{\circ} \mathrm{C}$ in a cell incubator. The suspensions of GMK, 769-P and HepG2 cells were prepared at a density of $1 \times 10^{6}$ cells $/ \mathrm{ml}$, prior to being transferred to 96-well cell culture plates (SPL Life Sciences, Pocheon, Korea). The prepared plates were incubated for $24 \mathrm{~h}$ in order for cells to adhere to the plates.

Drugs and substances. Drugs and substances were as follows: MTT (Sigma-Aldrich; Merck KGaA), dimethyl sulfoxide (DMSO; Avantor Performance Materials, Inc., Gliwice, Poland), phosphate-buffered saline (PBS; Biomed Serum and Vaccine Production Plant Ltd.), and The Eagle's minimal essential medium (EMEM; ATCC). The basic and rich-component RPMI-1640, FBS, and the penicillin, streptomycin, amphotericin B and trypsin solution $(0.25 \%$ trypsin and $0.02 \%$ EDTA in PBS without $\mathrm{Ca}^{2+}$ or $\mathrm{Mg}^{2+}$, with phenol red) were supplied by PAN-Biotech GmbH (Aidenbach, Germany).

Cell viability assay. Cell viability was assessed using an MTT assay based on DB-ALM protocol no. 17 (European Centre for the Validation of Alternative Methods, Database Service on Alternative Methods to Animal Experimentation). Cell viability was determined in a mitochondrial-dependent reaction (reduction in mitochondrial dehydrogenase activity) by measurement of the formazan production from MTT salt. Cell viability is expressed as the percentage (\%) of control cells. The examined compounds were first dissolved in DMSO and subsequently diluted to the required concentration with the respective cell culture medium. The solutions were prepared ex tempore, were added to the cells in the same volume $(100 \mu \mathrm{l} /$ well $)$ and incubated for $24 \mathrm{~h}$. Following incubation, $10 \mu \mathrm{l}$ MTT solution $(5 \mathrm{mg} / \mathrm{ml})$ was added to each well of a microplate and was incubated for $3 \mathrm{~h}$ at $37^{\circ} \mathrm{C}$. At the end of the incubation, the culture medium was removed carefully from each well and $100 \mu \mathrm{l}$ DMSO was added. The absorbance of each well was measured at $550 \mathrm{~nm}$ using an automated absorbance microplate reader $\mathrm{EL}_{\mathrm{x}} 808_{\mathrm{IU}}$ (BioTek Instruments Inc., Winooski, VT, USA). The experiments included the determination of $\mathrm{IC}_{10}, \mathrm{IC}_{25}$ and $\mathrm{IC}_{50}$ values for tested compounds. The cells were analyzed under a phase-contrast microscope (magnification, x150) Nikon Eclipse Ti (Nikon Corporation, Tokyo, Japan). Next, the cell cultures were incubated in the presence of tested compounds at concentrations of $\mathrm{IC}_{10}$ and $\mathrm{IC}_{25}$ during 24, 48 and $72 \mathrm{~h}$. All the parameters mentioned in the present study were evaluated in the presence of the solvent of 1,3-thiazolidin-4-one derivatives and there were no significant differences between the control cells and the solvent-treated cells. The final concentration of DMSO did not exceed $0.5 \% \mathrm{v} / \mathrm{v}$. All the experiments were performed at least five times.

The cell cycle and apoptosis of 769-P cells. Two-step cell cycle analysis was performed using the NucleoCounter NC-3000 system (ChemoMetec, Allerod, Denmark), according to the manufacturer's protocol. This system enables the rapid quantification of the DNA content of mammalian cells, allowing

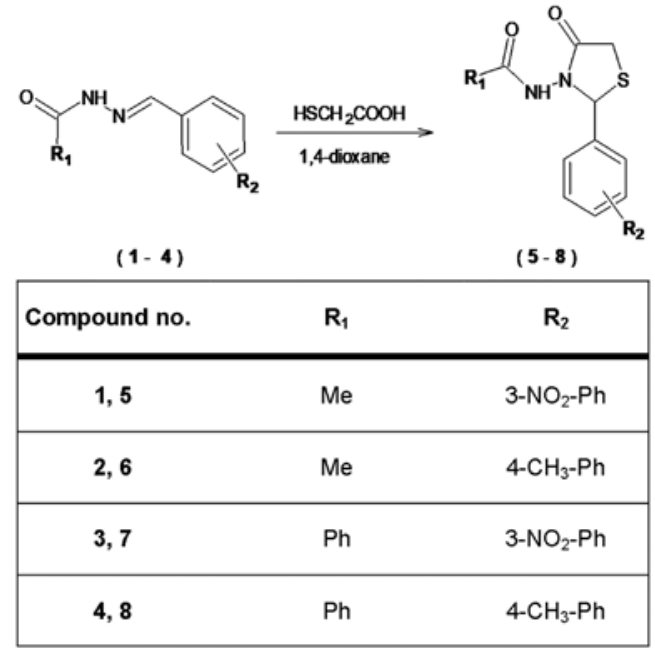

Figure 1. Synthetic pathway to 2,3-disubstituted 1,3-thiazolidin-4-one derivatives (compounds 5-8).

determination of G0/G1, S and G2/M cell cycle phases. The DNA content is measured using the fluorescent, DNA-selective stain, DAPI, which exhibits emission signals proportional to DNA mass. The Annexin V assay for the NucleoCounter NC-3000 system enables the measurement of externalization of phosphatidylserine. The translocation of the aforementioned phospholipid to the outer membrane layer indicates early apoptosis and fluorescently labeled Annexin V preferentially binds to negatively charged phosphatidylserine. Annexin V is a cellular protein that also binds to this phospholipid on late apoptotic and necrotic cells. However, as the membrane integrity of these cells has been lost, these can be distinguished from early apoptotic cells by the use of an impermeant dye, such as propidium iodide (PI). Cells were stained with an Annexin V-CF488A conjugate and with Hoechst 33342. Immediately prior to analysis, the cells are mixed with PI to stain non-viable cells. The quantification of early apoptotic cells was based on Annexin V binding and PI exclusion.

Statistical analysis. Results are expressed as the mean \pm standard error of the mean. The statistical significance among the groups was determined by analysis of variance, followed by Dunnett's post hoc test using Statistica software (version 12; Statsoft, Inc., Tulsa, OK, USA). $\mathrm{P}<0.05$ was considered to indicate a statistically significant difference.

\section{Results}

Chemistry. In the present study, 2,3-disubstituted 1,3-thiazolidin-4-one derivatives (5-8) were synthesized by the cyclization reaction of $\mathrm{N}$-substituted carboxylic acid hydrazide derivatives (1-4) with mercaptoacetic acid in the presence of 1,4-dioxane (Fig. 1), as previously described (25). The obtained compounds are stable solids at room temperature and their spectral data $\left({ }^{1} \mathrm{H} \mathrm{NMR},{ }^{13} \mathrm{C} \mathrm{NMR}\right)$ is in full agreement with the proposed structures. Synthesized compounds were evaluated for in vitro antiproliferative study.

In vitro cytotoxicity. The assessment of anticancer potential of 1,3-thiazolidin-4-one derivatives was performed in human 


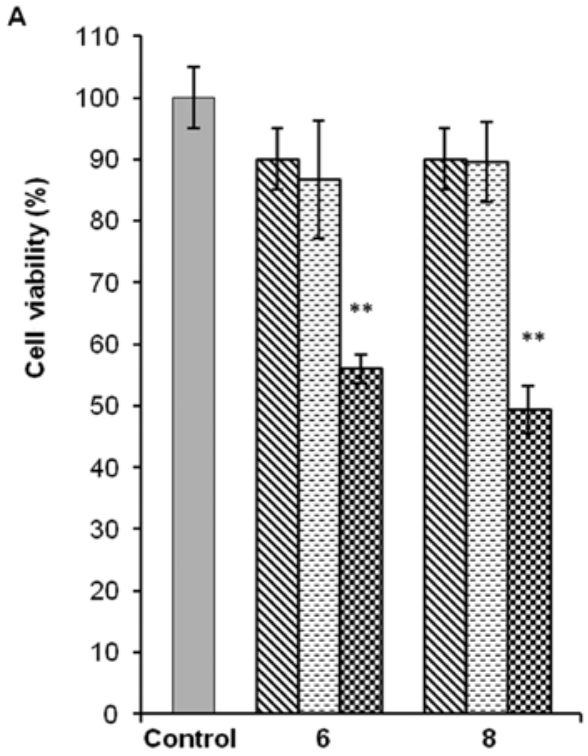

after 24-h incubation 标 after 48-h incubation

after 72-h incubation

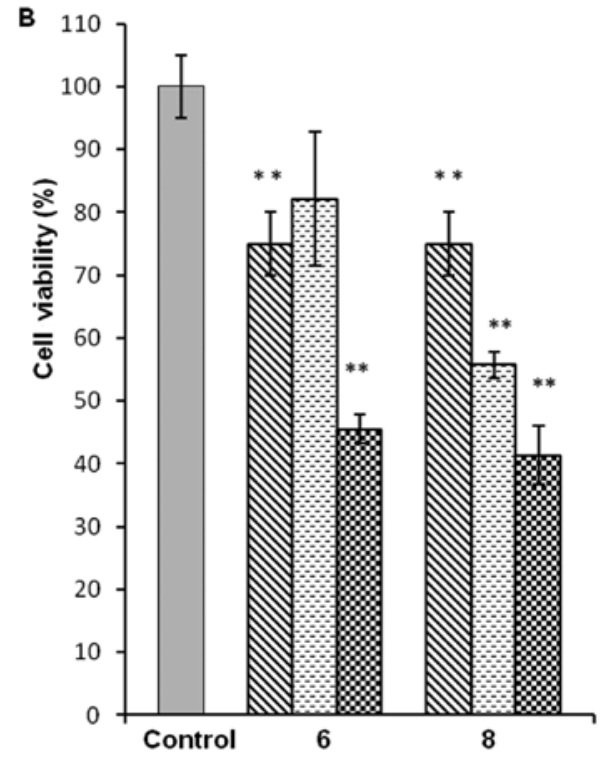

after 24-h incubation 蔆 after 48-h incubation

after 72-h incubation

Figure 2. Effect of 1,3-thiazolidin-4-one derivatives (compounds 6 and 8) on 769-P cell viability in the MTT test following application at a concentration of (A) $\mathrm{IC}_{10}$ or $(\mathrm{B}) \mathrm{IC}_{25}$. The final concentration of dimethyl sulfoxide did not exceed $0.5 \% \mathrm{v} / \mathrm{v}$. Data are presented as the percentage of cell viability \pm standard error of the mean. ${ }^{* *} \mathrm{P}<0.01$ vs. control cells. IC, inhibitory concentration.

Table I. The determination of IC for 1,3-thiazolidin-4-one derivatives (compounds 5-8).

\begin{tabular}{lcccc}
\hline & \multicolumn{4}{c}{ Cell line } \\
\cline { 2 - 5 } Compound no. & $\mathrm{IC}, \mathrm{mM}$ & $\mathrm{GMK}$ & $769-\mathrm{P}$ & HepG2 \\
\hline 5 & $\mathrm{IC}_{10}$ & 0.73 & nd & 0.95 \\
& $\mathrm{IC}_{25}$ & 2.34 & nd & 2.90 \\
& $\mathrm{IC}_{50}$ & 16.48 & nd & 18.62 \\
6 & $\mathrm{IC}_{10}$ & 0.64 & 0.69 & 0.31 \\
& $\mathrm{IC}_{25}$ & 1.09 & 1.15 & 0.7 \\
& $\mathrm{IC}_{50}$ & 2.66 & 2.67 & 2.70 \\
7 & $\mathrm{IC}_{10}$ & nd & nd & 0.64 \\
& $\mathrm{IC}_{25}$ & nd & nd & 2.03 \\
8 & $\mathrm{IC}_{50}$ & 33.85 & nd & 13.67 \\
& $\mathrm{IC}_{10}$ & 0.59 & 0.81 & 0.51 \\
& $\mathrm{IC}_{25}$ & 0.96 & 1.31 & 0.75 \\
& $\mathrm{IC}_{50}$ & 2.13 & 2.93 & 1.43 \\
\hline
\end{tabular}

IC, inhibitory concentration; nd, not determined.

renal cell adenocarcinoma (769-P) and human hepatoblastoma-derived cells (HepG2) (9), and green monkey kidney cells (GMK) as a normal reference cell line, using the MTT method. The $\mathrm{IC}_{10}, \mathrm{IC}_{25}$ and $\mathrm{IC}_{50}$ values for compounds 5-8 were determined based on dose-response curves (Table I).

After $72 \mathrm{~h}$ of incubation of human renal adenocarcinoma cells (769-P) with compound 6 at $\mathrm{IC}_{10}$ and compound 8 at $\mathrm{IC}_{10}$ the significant reductions of cell viability by $\sim 50 \%$ were noted compared with the control (Fig. 2A). Additionally,

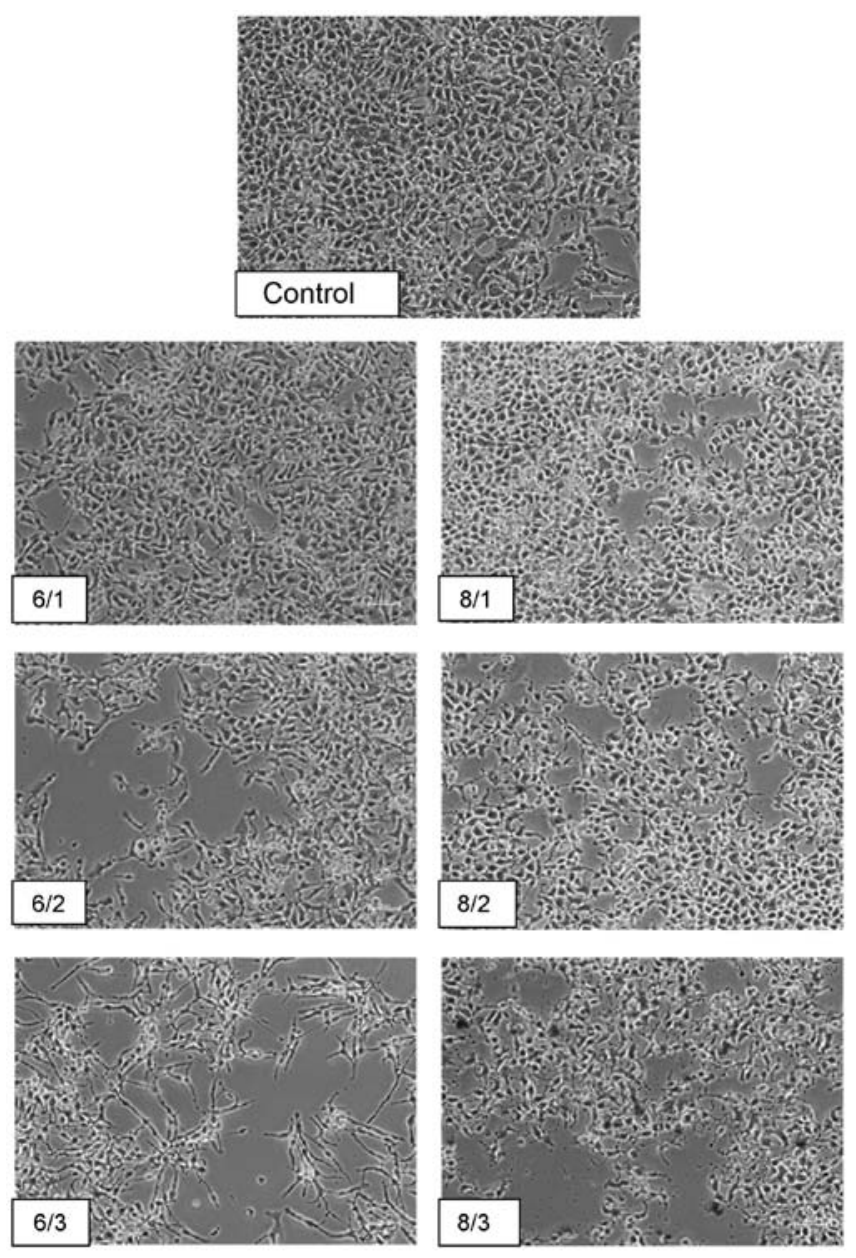

Figure 3. Morphological changes in 769-P cells associated with different inhibitory concentrations of 1,3-thiazolidin-4-one derivatives (compounds 6 and 8 ) after $24 \mathrm{~h}$ of incubation (magnification, x150). Concentrations: $1, \mathrm{IC}_{10}$; $2, \mathrm{IC}_{25}$; and $3, \mathrm{IC}_{50}$. IC, inhibitory concentration. 

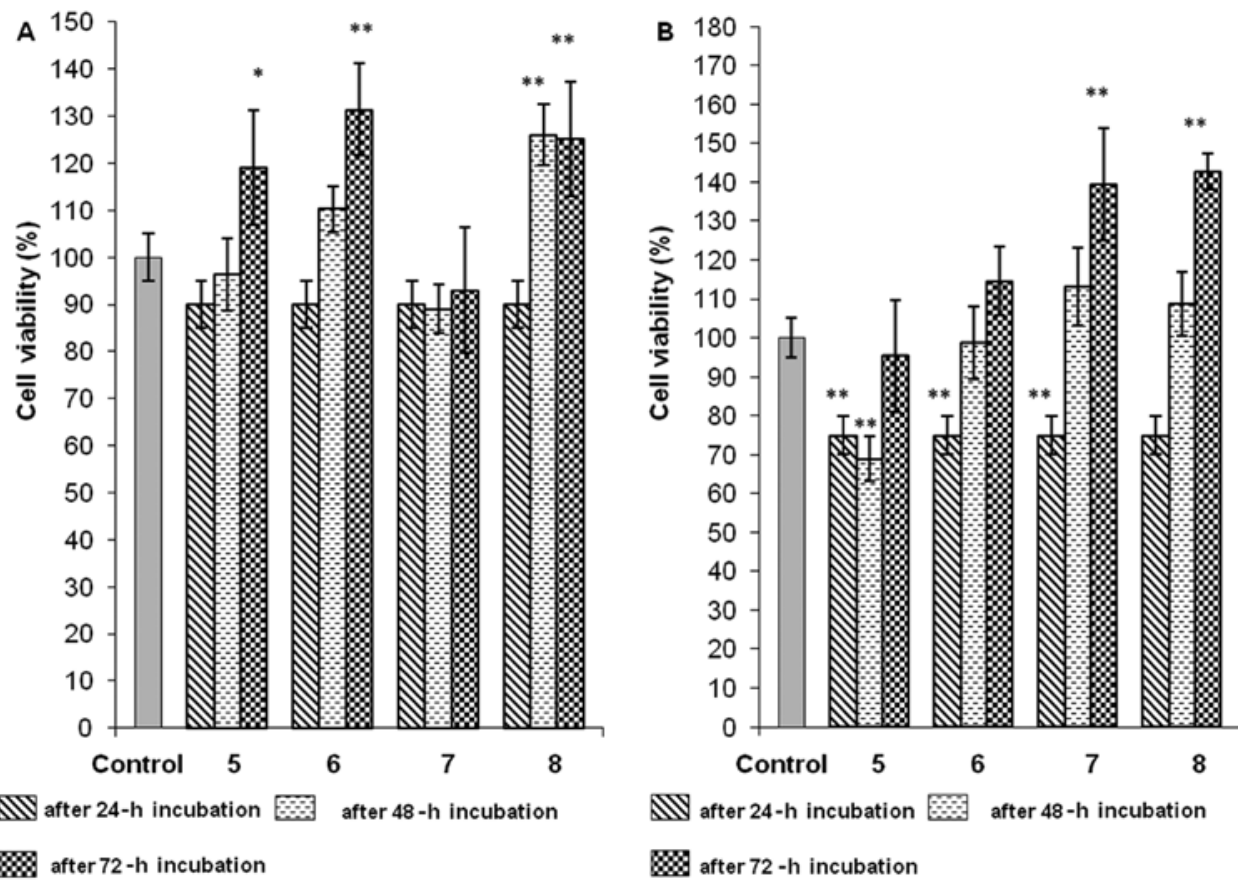

Figure 4. Effect of 1,3-thiazolidin-4-one derivatives (compounds 5-8) on the viability of HepG2 cells in the MTT test following application at a concentration of $(\mathrm{A}) \mathrm{IC}_{10}$ and $(\mathrm{B}) \mathrm{IC}_{25}$. The final concentration of DMSO did not exceed $0.5 \% \mathrm{v} / \mathrm{v}$. Data are presented as the percentage of cell viability \pm standard error of the mean. ${ }^{*} \mathrm{P}<0.05$ and ${ }^{* *} \mathrm{P}<0.01$ vs. control cells. IC, inhibitory concentration.

Table II. Effect of 1,3-thiazolidin-4-one derivatives (compounds 6 and 8) on the viability of GMK cells after 24,48 or 72 h of incubation.

\begin{tabular}{lcccc}
\hline & \multicolumn{4}{c}{ Viability of the cells following incubation, \% } \\
\cline { 2 - 5 } Compound no. & Concentration & $24 \mathrm{~h}$ & $48 \mathrm{~h}$ & $72 \mathrm{~h}$ \\
\hline 6 & $\mathrm{IC}_{10}$ & $88.21 \pm 4.32$ & $72.28 \pm 6.33^{\mathrm{a}}$ & $78.36 \pm 8.26^{\mathrm{a}}$ \\
& $\mathrm{IC}_{25}$ & $73.38 \pm 4.54^{\mathrm{a}}$ & $65.65 \pm 2.52^{\mathrm{a}}$ & $64.11 \pm 3.25^{\mathrm{a}}$ \\
& $\mathrm{IC}_{10}$ & $92.03 \pm 5.98$ & $76.79 \pm 8.26^{\mathrm{a}}$ & $60.01 \pm 1.88^{\mathrm{a}}$ \\
& $\mathrm{IC}_{25}$ & $77.25 \pm 6.15^{\mathrm{a}}$ & $80.38 \pm 9.80^{\mathrm{a}}$ & $43.79 \pm 1.36^{\mathrm{a}}$ \\
\hline
\end{tabular}

Data are presented as the percentage of cell viability \pm standard error of the mean. ${ }^{\text {a }}<<0.01 \mathrm{vs}$. control cells.

following incubation of 769-P cells with compound 6 , the decreases in cell viability were almost the same for $\mathrm{IC}_{10}$ and $\mathrm{IC}_{25}$ (Fig. $2 \mathrm{~A}$ and $\mathrm{B}$ ). Compound 8 at a concentration of $\mathrm{IC}_{25}$ evoked a time-dependent decrease in the viability of 769-P cells $(45 \%$ growth inhibition after $48 \mathrm{~h}$ and $60 \%$ after $72 \mathrm{~h}$, compared with the control; Fig. 2B). After a 24-h incubation period of 769-P cells with the aforementioned compounds at concentrations of $\mathrm{IC}_{10}, \mathrm{IC}_{25}$ and $\mathrm{IC}_{50}$, they were evaluated using a phase-contrast microscope (magnification, $\mathrm{x} 150$ ). The adverse changes in their general morphology and the reduction in the cell culture density resulted from the inhibitory concentration used. The occurrence of irregularly shaped cells resulting from shrinkage of the cytoplasm and inhibition of contact growth were already observed at the lowest $\mathrm{IC}_{10}$ concentration, particularly in the case of compound 8 . At the highest concentration corresponding to $\mathrm{IC}_{50}$ in the field of vision beyond the aforementioned changes, a small number of detached and dead cells were observed (Fig. 3). This derivative used in the all determined inhibitory concentrations caused clearly visible cell damage after $24 \mathrm{~h}$ of incubation. The number of cell deformations and the extent of growth inhibition corresponded with the increasing concentration (Fig. 3).

Compounds 5, 6 and 8, applied at concentrations of $\mathrm{IC}_{10}$ to the cancer HepG2 cell line, significantly increased cell viability by $20-30 \%$ in a time-dependent manner, when compared with the control (Fig. 4A). Similar results were obtained for compound 8 at a concentration of $\mathrm{IC}_{25}$ (Fig. 4B). Increasing the concentrations to $\mathrm{IC}_{25}$ for compound 5 and 6 also caused the enhancement of HepG 2 cell viability after $48 \mathrm{~h}$ and $72 \mathrm{~h}$ of incubation, but not to above that of the control cells (Fig. 4B). In the case of compound 7 at $\mathrm{IC}_{10}$, the time of incubation had no impact on the $10 \%$-cytotoxic effect, but at $\mathrm{IC}_{25}$, a very significant and time-dependent increase in cell viability was observed (Fig. 4A and B).

The 48-h and 72-h incubation periods of GMK cells with compound 6 at a concentration of $\mathrm{IC}_{10}$ caused an increase in the cytotoxic effect by $\sim 30$ and $20 \%$, respectively, compared with the control (Table II). A larger decrease in viability 


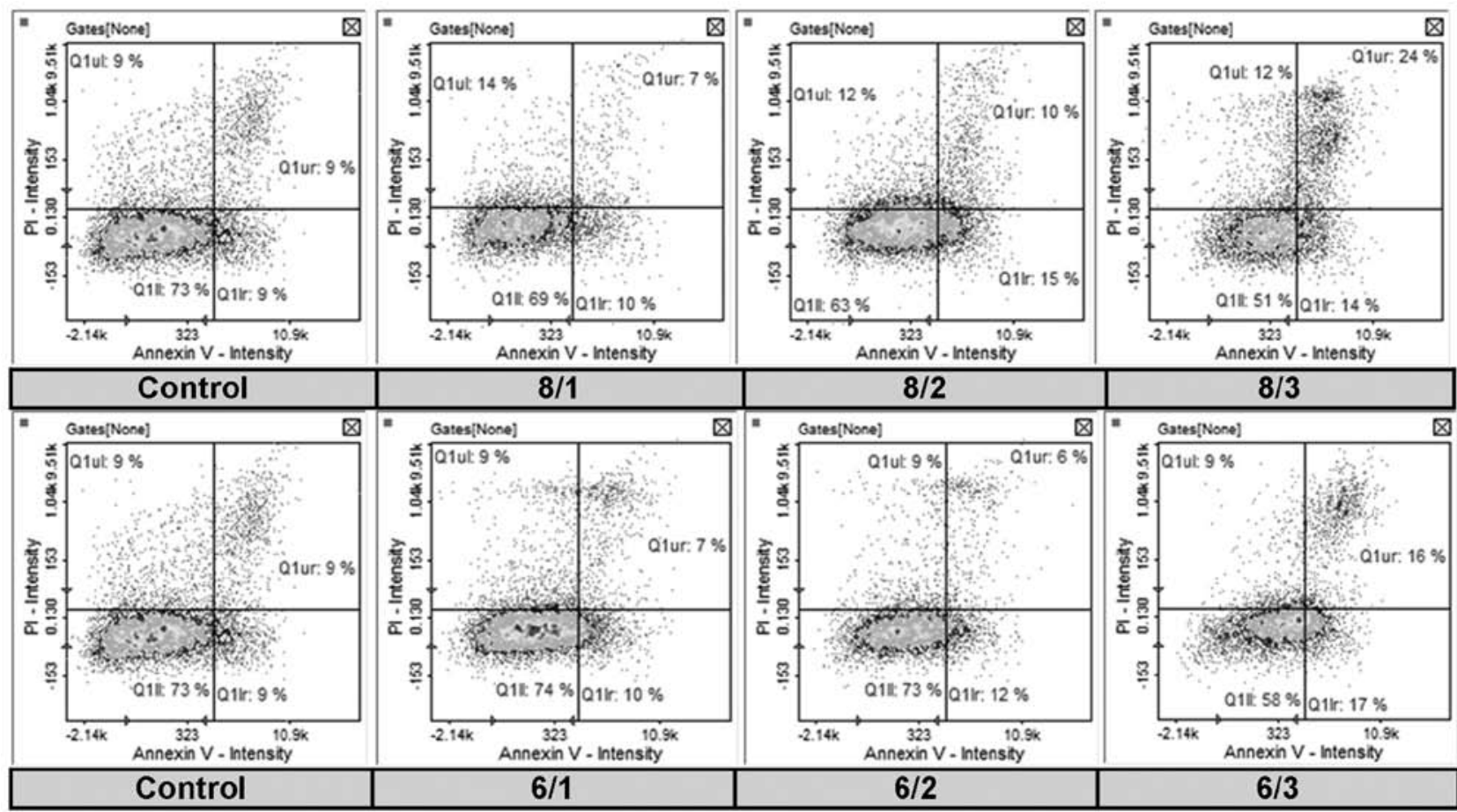

Figure 5. Apoptotic effect of 1,3-thiazolidin-4-one derivatives (compounds 6 and 8) on the apoptosis of 769-P cells after $24 \mathrm{~h}$ of treatment with different inhibitory concentrations. Concentration: $1, \mathrm{IC}_{10} ; 2, \mathrm{IC}_{25}$; and 3, $\mathrm{IC}_{50}$. Scatter plots demonstrate Annexin V-CF488A intensity versus the intensity of PI. They are divided into four internal squares: Left lower square shows healthy cells, right lower square shows early apoptotic cells, right upper square shows late apoptotic cells, and left upper square shows necrotic cells. IC, inhibitory concentration; PI, propidium iodide.

Table III. Impact of different inhibitory concentrations of 1,3-thiazolidin-4-one derivatives (compounds 6 and 8) on the apoptosis of 769-P cells after $24 \mathrm{~h}$ of incubation.

\begin{tabular}{lcccc}
\hline $\begin{array}{l}\text { Compound no./ } \\
\text { concentration }\end{array}$ & $\begin{array}{c}\text { Healthy, } \\
\text { cells, \% }\end{array}$ & $\begin{array}{c}\text { Early } \\
\text { apoptotic } \\
\text { cells, \% }\end{array}$ & $\begin{array}{c}\text { Late } \\
\text { apoptotic } \\
\text { cells, } \%\end{array}$ & $\begin{array}{c}\text { Necrotic } \\
\text { cells, \% }\end{array}$ \\
\hline Control & 72.9 & 9.1 & 9.0 & 9.0 \\
$6 / 1$ & 74.0 & 10.1 & 6.7 & 9.2 \\
$6 / 2$ & 58.0 & 16.7 & 16.4 & 8.9 \\
$6 / 3$ & 73.4 & 11.6 & 6.4 & 8.6 \\
$8 / 1$ & 69.4 & 8.4 & 6.5 & 15.7 \\
$8 / 2$ & 63.4 & 14.7 & 10.0 & 12.0 \\
$8 / 3$ & 50.9 & 13.8 & 23.6 & 11.6 \\
\hline
\end{tabular}

Concentration: $1, \mathrm{IC}_{10} ; 2, \mathrm{IC}_{25} ; 3, \mathrm{IC}_{50}$.

( $40 \%$ vs. control) was noted after $72 \mathrm{~h}$ of incubation of the aforementioned cells with compound 8 at $\mathrm{IC}_{10}$. The decrease in the viability of cells incubated with derivative 8 was also time-dependent (Table II). Following 48-h and 72-h incubation with compound 6 at $\mathrm{IC}_{25}$, the increase in concentration resulted in slight increase in cytotoxic effect by $\sim 35 \%$ (Table II). However, compound 8 at $\mathrm{IC}_{25}$ led to the most significant decrease (almost $60 \%$ vs. control) in cell viability after $72 \mathrm{~h}$ (Table II).

Annexin V assay. Since a significant dose- and time-dependent inhibitory effect of compounds 6 and 8 on 769-P cells was observed, it was investigated whether these novel derivatives
Table IV. 769-P cell cycle analysis following 24-h incubation with differentinhibitory concentrations of 1,3-thiazolidin-4-one derivatives (compounds 6 and 8 ).

\begin{tabular}{lcccc}
\hline & \multicolumn{4}{c}{ Stage } \\
\cline { 2 - 5 } $\begin{array}{l}\text { Compound no./ } \\
\text { concentration }\end{array}$ & Sub-G0, $\%$ & G1, \% & S, \% & G2, \% \\
\hline Control & 4.5 & 69.4 & 3.9 & 21.1 \\
$6 / 1$ & 4.7 & 89.3 & 1.3 & 4.3 \\
$6 / 2$ & 4.4 & 89.7 & 1.2 & 4.4 \\
$6 / 3$ & 4.7 & 92.1 & 1.0 & 1.9 \\
$8 / 1$ & 7.1 & 77.9 & 3.4 & 11.0 \\
$8 / 2$ & 7.9 & 79.9 & 4.3 & 8.2 \\
$8 / 3$ & 6.0 & 89.8 & 1.9 & 2.0 \\
\hline
\end{tabular}

Concentration: $1, \mathrm{IC}_{10} ; 2, \mathrm{IC}_{25} ; 3, \mathrm{IC}_{50}$.

caused apoptosis in 769-P cells, which was determined by Annexin V and PI double staining (Fig. 5). The apoptosis rate of the cells treated with compounds 6 at $\mathrm{IC}_{25}$ was almost two times higher than that in the control group (Table III). When compound 8 was applied at $\mathrm{IC}_{25}$ or $\mathrm{IC}_{50}$, the number of early and late apoptotic cells was increased in comparison to the untreated cells from 18.1 to 24.7 or $37.4 \%$, compared with the inhibitory concentration (Table III). The aforementioned increase was also dose-dependent. In the cells treated with compound 8 applied at $\mathrm{IC}_{10}, \mathrm{IC}_{25}$ or $\mathrm{IC}_{50}$ when compared with the control cells, a dose-dependent decrease in the number 
of healthy cells (from 72.9 to a maximum of $50.9 \%$ ) and an increased in the number of necrotic cells (from 9 to a maximum of $15.7 \%$ ) were observed (Table III).

Cell cycle assay. The effect of compounds 6 and 8 on the cell cycle progression of 769-P cells was determined. As demonstrated in Table IV, compared with the control, compound 6 increased the population of cells in the G1 phase from 69.4 to a maximum of $92.1 \%$ in a dose-dependent manner. Additionally, a dose-dependent decrease in the $\mathrm{S}$ phase (from 3.9 to a maximum of $1 \%$ ) and $\mathrm{G} 2$ phase (from 21.1 to a maximum of $1.9 \%$ ) cell population was observed. 769-P cell accumulation in the G1 fraction was also observed following cell exposure to compound 8 and the number of cells increased from 69.4 to a maximum of $89.8 \%$ as the inhibitory concentration increased (Table IV). Notably, cell treatment with compound 8 increased cell distribution in the sub-G0 stage of the cell cycle, which is consistent with the results of identification of apoptotic cells (Tables III and IV). Additionally, as demonstrated in Table IV, the number of 769-P cells at the G2 phase in the treatment groups was lower than in the control group, and this decrease was dose-dependent (from 21.1 to a maximum of $2 \%$ ).

\section{Discussion}

Taking into consideration the incidence and mortality rates, there is an urgent requirement to investigate novel molecules targeting tumors, including renal cell carcinoma or hepatoblastoma (3-8). The 1,3-thiazolidin-4-ones are of great importance on the design and synthesis of novel biologically active agents $(15,16)$. In the present study, when the chemical structures of synthesized 1,3-thiazolidin-4-ones were confirmed by spectral data, their anticancer potential was evaluated in in vitro experiments. The thiazolidin-4-one moiety is a biologically proven anticancer pharmacophore and substitution in this scaffold may further enhance its activity $(15-16,30,33)$. It is known that substituents may be varied but the greatest significance in properties is exerted by the group attached to the carbon atom at the 2-position of the thiazolidinone heterocycle (16). In particular, 2-aryl-1,3-thiazolidin-4-ones demonstrated considerable cytotoxic effect against human cancer cell cultures $(16,34)$. Therefore, the MTT cell viability assay of newly synthesized 2,3-disubstituted 1,3-thiazolidin-4-ones was performed against the renal cell adenocarcinoma 769-P cell line, the hepatoblastoma-derived HepG 2 cell line and the normal cell line (GMK) as reference (9). In the present study, among novel 4-thiazolidinone derivatives, compound 6 was the most toxic against 769-P cells and compound 8 exhibited similar properties, which may be associated with 4-methylphenyl at the 2-position of the thiazolidin-4-one moiety. They inhibited cancer cell growth with $\mathrm{IC}_{50}$ values estimated at $2.67 \mathrm{mM}$ (compound 6) and $2.93 \mathrm{mM}$ (compound 8). Compound 8 caused a significant, dose- and time-dependent decrease in cell viability up to $60 \%$ $(\mathrm{P}<0.01)$. Whereas derivative 6 possessed more promising activity by being more selective with respect to the cancer line. With regards to cancer cell culture (769-P), the incubation time appeared to also be crucial in the case of compound 6 , and after $72 \mathrm{~h}$ a significant $(\mathrm{P}<0.01) \sim 50 \%$ growth inhibition was noted for the two concentrations used. However, in the normal cell line, minor decreases in viability were observed with regard to increasing dose or time of incubation. It was hypothesized that 1,3-thiazolidin-4-one structure, which is 2-substituted with $p$-methylphenyl fragment, may be essential for the antiproliferative properties against the cancer 769-P cell line. The compounds with electron donating groups at the C-terminal of the phenyl ring were revealed to exhibit increased activity in inducing cancer cell death (15). It was demonstrated that, among 2,3-disubstituted thiazolidinone derivatives with phenyl ring at position 2, the groups attached to phenyl moiety are essential for anticancer activity $(30,34)$. The nitro group is a structural moiety that is frequently observed in biologically active molecules $(15,16)$. Joseph et al (30) reported that the $o$-nitro group at the phenyl ring of thiazolidin-4-one scaffold conferred maximum activity in the human breast adenocarcinoma MCF-7 cell line. However, a previous study on human breast cancer BT-549 cells and HeLa cells revealed that 2,3-diaryl thiazolidinones substituted with nitro group at ortho and para positions of the phenyl ring exhibited moderate antiproliferative properties (34). It may be concluded that our newly-synthesized substances, compounds $\mathbf{5}$ and $\mathbf{7}$ with meta-nitro phenyl, demonstrated slight anticancer activity in HepG2. The electronic influences of the substituents in the phenyl ring appear to serve an important role in anticancer activity, but this behavior also depends on the cancer cell lines being used (29). With regards to $\mathrm{IC}_{50}$ values estimated in 769-P and HepG2 cell lines, it may be stated that the substitution at the 2 position of thiazolidinone heterocycle with 4-methylphenyl is more favorable than with 3-nitrophenyl and that this significantly enhances the antiproliferative properties of the derivative tested. In turn, Kunzler et al (35) revealed that when 2,3-dubstituted 1,3-thiazolidin-4-ones with a phenyl ring at position 2 was tested on the normal monkey kidney Vero cell line, compared with GMK, the 3-nitro group in the phenyl ring was more cytotoxic than 4-methylphenyl (35). However, the results of the present study demonstrated the opposite. Therefore, it may be hypothesized that the scaffold at position 3 of thiazolidin-4-one moiety is of a great importance for normal cell line viability. The results of the present study demonstrated that $N$-substitution of newly developed compounds with acetamide moiety is less harmful than with benzamide one.

The more detailed analysis of the antiproliferative potential of compounds 6 and 8 in 769-P cells included a cell cycle assay and apoptosis analysis. It demonstrated that the cancer cells accumulated particularly in the G1 phase, while the number of 769-P cells in the G2 stage was lower than the number of untreated cells in the G2 stage. This decrease was dose-dependent, and may be associated with the inhibition of tubulin synthesis, which prevents mitosis. Another recent study demonstrated that the combination of mTOR inhibitor approved for advanced RCC and MEK1 inhibitor, which is currently used in clinical trials, also causes G1 cell cycle arrest (36). Therefore, it is known that PI3K/AKT/mTOR and RAS/MEK/ERK are the most critical pathways in carcinogenesis and tumor progression, but further investigation into the possible mechanisms of this are required for the aforementioned novel molecules (36). In addition, the application of compound 8 to 769-P cells also caused a decrease in the number of cells in the $\mathrm{S}$ phase in a dose-dependent 
manner. Taken together, these results suggested that the two molecule treatments were associated with cytostatic cell growth arrest. It is known that during the G1 phase, various enzymes required for $\mathrm{S}$-phase replication are synthesized. G1 cell cycle arrest and a decrease in the number of cells in the $\mathrm{S}$ phase indicated serious disturbances in cellular enzymatic activity. This is supported by the results of MTT assay, which revealed the impairment of the enzymes involved in tetrazolic salt metabolism in mitochondria. This suggested metabolic dysfunction and decreased mitochondrial reserve capacity in 769-P cells following exposure to 1,3-thiazolidin-4-one derivatives. Mitochondria serve a pivotal role in the initiation and amplification of the majority of apoptotic pathways. The mitochondrial membrane permeability increases when mitochondria are stimulated by apoptotic signals $(28,37)$. The results of the apoptosis assay indicated that the two tested derivatives increased the number of apoptotic cells in 769-P cell culture when they were added at higher inhibitory concentrations. Compound 8 had a clear ability to induce apoptotic cell death and it was demonstrated in a more consistent way, compared with compound 6 . It may be associated with benzamide scaffold at position 3 of the thiazolidin-4-one moiety and the presence of a phenyl ring may be crucial for the aforementioned changes. In brief, all the aforementioned assays confirmed the antiproliferative and pro-apoptotic effects of the two compounds on renal cell adenocarcinoma cells (769-P). Considering the molecular basis of RCC, the development of targeted agents should also include the inhibitory potential associated with intracellular signal transduction pathways that drive angiogenesis (36). Furthermore, a recent study demonstrated that newly identified steroidal thiazolidin-4-ones exhibited significant anti-angiogenic effects (33). Our future studies may include these novel perspectives.

The research performed on the cancer HepG2 cell line indicated compound 8 as the most promising with $\mathrm{IC}_{50}$ estimated at $1.43 \mathrm{mM}$. Unfortunately, prolonged incubation revealed undesirable increases in cell viability. Compound 7 exhibited an $\mathrm{IC}_{50}$ value that was three times higher than that for normal cells, compared with analogous values for cancer cells. Additionally, compound 7 applied at $\mathrm{IC}_{10}$ preserved antiproliferative activity during 48- and 72-h incubation periods. The more detailed studies demonstrated that compound 7 incubated with HepG2 cells at a higher concentration caused, like derivative 8 , undesirable cell growth enhancement.

In conclusion, 2,3-disubstituted 1,3-thiazolidin-4-one derivatives were successfully prepared in the present study using the cyclization reaction of appropriate $N$-substituted carboxylic acid hydrazides with mercaptoacetic acid, as previously described (25). All prepared compounds were subjected to in vitro study of cytotoxicity towards human cancer cell lines. It was observed that generally 2,3-substituted thiazolidinones were characterized by diverse cytotoxicity, whereas $\mathrm{N}$-[2(4-methylphenyl)-4-oxo-1,3-thiazolidin-3-yl]acetamide (6) and $N$-[2-(4-methylphenyl)-4-oxo-1,3-thiazolidin-3-yl]benzamide (8) appeared to be the most active against human renal adenocarcinoma 769-P cells and significantly decreased their viability in a dose- and time-dependent manner. The results obtained suggested that the most prominent cytotoxicity could be partially attributed to the electron-donating methyl group at the 4-position of phenyl ring. These compounds were responsible for G1 cell cycle arrest in 769-P cells. The two derivatives also decreased cell distribution in the G2 phase in a dose-dependent manner. In turn, cell treatment with compound 8 caused an increase in the number of cells in the sub-G0 stage, which is consistent with the results of identification of apoptotic cells. For the aforementioned newly developed molecule, the ability to induce apoptotic cell death may be associated with the benzamide moiety. The presented results clearly indicated that the aforementioned novel 2,3-disubstituted 1,3-thiazolidin-4-ones induced cell cycle arrest and apoptosis in human renal adenocarcinoma cells (769-P) in a dose-dependent manner.

\section{Acknowledgements}

Not applicable.

\section{Funding}

The present study was supported by Funds for Statutory Activity of Medical University of Lublin, Poland (grant no. DS38/2014-2015).

\section{Availability of data and materials}

All data generated and/or analyzed during this study are included in this published article.

\section{Authors' contributions}

MGG, ŁP and DNC designed and directed the experiment. MGG wrote the manuscript (excluding part describing the synthesis and chemical structure identification of tested compounds). ŁP designed, synthesized, purified and identified by spectral methods 1,3-thiazolidin-4-one derivatives and wrote the part of manuscript regarding these processes. MGG, DNC and IPC performed the in vitro cytotoxicity study. DNC and MIz analyzed/collected the data. DNC performed the statistical analysis. DNC and $\mathrm{MH}$ interpreted the results of statistical analysis. MH was involved in drafting the manuscript and revised critically the final version of the manuscript. MIw performed the cell cycle assay and Annexin V assay and microscopic analysis and collected the data. AK, JD and MW were involved in the conception of the study. AK supervised cell cycle and Annexin V assays, JD supervised the in vitro cytotoxicity study, MW supervised the synthesis and spectral identification of novel derivatives. AK, JD and MW revised critically the final version of the manuscript. All authors read and approved the final manuscript.

\section{Ethics approval and consent to participate}

Not applicable.

\section{Patient consent for publication}

Not applicable.

\section{Competing interests}

The authors declare that they have no competing interests. 


\section{References}

1. Gregorić T, Sedić M, Grbčić P, Tomljenović Paravić A Kraljević Pavelić S, Cetina M, Vianello R and Raić-Malić S: Novel pyrimidine-2,4-dione-1,2,3-triazole and furo[2,3-d] pyrimidine-2-one-1,2,3-triazole hybrids as potential anti-cancer agents: Synthesis, computational and X-ray analysis and biological evaluation. Eur J Med Chem 125: 1247-1267, 2017.

2. Escudier B, Porta C, Schmidinger M, Algaba F, Patard JJ, Khoo V, Eisen T and Horwich A; ESMO Guidelines Working Group: Renal cell carcinoma: ESMO Clinical Practice Guidelines for diagnosis, treatment and follow-up. Ann Oncol 25 (Suppl 3): iii49-iii56, 2014.

3. Meyers RL, Tiao G, de Ville de Goyet J, Superina R and Aronson DC: Hepatoblastoma state of the art: Pre-treatment extent of disease, surgical resection guidelines and the role of liver transplantation. Curr Opin Pediatr 26: 29-36, 2014.

4. Sumazin P, Chen Y, Treviño LR, Sarabia SF, Hampton OA, Patel K, Mistretta TA, Zorman B, Thompson P, Heczey A, et al: Genomic analysis of hepatoblastoma identifies distinct molecular and prognostic subgroups. Hepatology 65: 104-121, 2017.

5. Ridge CA, Pua BB and Madoff DC: Epidemiology and staging of renal cell carcinoma. Semin Intervent Radiol 31: 3-8, 2014.

6. Stewart BW and Wild CP (eds.): World Cancer Report 2014. International Agency for Research on Cancer, Lyon, 2014.

7. Znaor A, Lortet-Tieulent J, Laversanne M, Jemal A and Bray F: International variations and trends in renal cell carcinoma incidence and mortality. Eur Urol 67: 519-530, 2015

8. Kabaria R, Klaassen Z and Terris MK: Renal cell carcinoma: Links and risks. Int J Nephrol Renovasc Dis 9: 45-52, 2016.

9. López-Terrada D, Cheung SW, Finegold MJ and Knowles BB: Hep G2 is a hepatoblastoma-derived cell line. Hum Pathol 40: $1512-1515,2009$

10. Chen Z, Zhang J, Zhang Z, Feng Z, Wei J, Lu J, Fang Y, Liang Y, Cen J, Pan Y, et al: The putative tumor suppressor microRNA-30a-5p modulates clear cell renal cell carcinoma aggressiveness through repression of ZEB2. Cell Death Dis 8: e2859, 2017.

11. Chen T, Ji B and Chen Y: Tetrandrine triggers apoptosis and cell cycle arrest in human renal cell carcinoma cells. J Nat Med 68: 46-52, 2014

12. Roseweir AK, Qayyum T, Lim Z, Hammond R, MacDonald AI, Fraser S, Oades GM, Aitchison M, Jones RJ and Edwards J: Nuclear expression of Lyn, a Src family kinase member, is associated with poor prognosis in renal cancer patients. BMC Cancer 16: 229, 2016

13. Fang Y, Wei J, Cao J, Zhao H, Liao B, Qiu S, Wang D, Luo J and Chen W: Protein expression of ZEB2 in renal cell carcinoma and its prognostic significance in patient survival. PLoS One 8 : e62558, 2013

14. Yuan ZX, Mo J, Zhao G, Shu G, Fu HL and Zhao W: Targeting strategies for renal cell carcinoma: From renal cancer cells to renal cancer stem cells. Front Pharmacol 7: 423, 2016.

15. Jain AK, Vaidya A, Ravichandran V,Kashaw SK and Agrawal RK Recent developments and biological activities of thiazolidinone derivatives: A review. Bioorg Med Chem 20: 3378-3395, 2012.

16. Tripathi AC, Gupta SJ, Fatima GN, Sonar PK, Verma A and Saraf SK: 4-Thiazolidinones: The advances continue.... Eur J Med Chem 72: 52-77, 2014

17. Murugesan V, Tiwari VS, Saxena R, Tripathi R, Paranjape R, Kulkarni S, Makwana N, Suryawanshi R and Katti SB: Lead optimization at C-2 and N-3 positions of thiazolidin-4-ones as HIV-1 non-nucleoside reverse transcriptase inhibitors. Bioorg Med Chem 19: 6919-6926, 2011.

18. Omar K, Geronikaki A, Zoumpoulakis P, Camoutsis C, Soković M, Cirić A and Glamoclija J: Novel 4-thiazolidinone derivatives as potential antifungal and antibacterial drugs. Bioorg Med Chem 18: 426-432, 2010.

19. Popiołek Ł, Stefańska J, Kiełczykowska M, Musik I, Biernasiuk A Malm A and Wujec M: Synthesis, dissociation constants, and antimicrobial activity of novel 2,3-disubstituted-1,3-thiazolidin-4-one derivatives. J Chem 53: 393-402, 2016.

20. Rawal RK, Tripathi R, Katti SB, Pannecouque C and De Clercq E: Synthesis and evaluation of 2-(2,6-dihalophenyl)-3-pyrimidinyl-1,3-thiazolidin-4-one analogues as anti-HIV-1 agents. Bioorg Med Chem 15: 3134-3142, 2007.
21. Bielenica A, Szulczyk D, Olejarz W, Madeddu S, Giliberti G, Materek IB, Koziol AE and Struga M: 1H-Tetrazol-5-amine and 1,3-thiazolidin-4-one derivatives containing 3-(trifluoromethyl) phenyl scaffold: Synthesis, cytotoxic and anti-HIV studies. Biomed Pharmacother 94: 804-812, 2017.

22. Archana, Srivastava VK and Kumar A: Synthesis of newer thiadiazolyl and thiazolidinonyl quinazolin-4 $3 H$-ones as potential anticonvulsant agents. Eur J Med Chem 37: 873-882, 2002.

23. Diurno MV, Mazzoni O, Correale G, Gomez Monterrey I, Calignano A, La Rana G and Bolognese A: Synthesis and structure-activity relationships of 2-(substituted phenyl)3-[3-(N,N-dimethylamino)propyl]-1,3-thiazolidin-4-ones acting as H1-histamine antagonists. Farmaco 54: 579-583, 1999.

24. Firke SD, Firake BM, Chaudhari RY and Patil R: Synthetic and pharmacological evaluation of some pyridine containing thiazolidinones. Asian J Res Chem 2: 157-161, 2009.

25. Popiołek $\succeq$, Biernasiuk A and Malm A: Synthesis and antimicrobial activity of new 1,3-thiazolidin-4-one derivatives obtained from carboxylic acid hydrazides. Phosphorus Sulfur 190: 251-260, 2015 .

26. Wang S, Zhao Y, Zhang G, Lv Y, Zhang N and Gong P: Design, synthesis and biological evaluation of novel 4-thiazolidinones containing indolin-2-one moiety as potential antitumor agent. Eur J Med Chem 46: 3509-3518, 2011.

27. Zhou H, Wu S, Zhai S, Liu A, Sun Y, Li R, Zhang Y, Ekins S, Swaan PW, Fang B, et al: Design, synthesis, cytoselective toxicity, structure-activity relationships, and pharmacophore of thiazolidinone derivatives targeting drug-resistant lung cancer cells. J Med Chem 51: 1242-1251, 2008.

28. Sharath Kumar KS, Hanumappa A, Vetrivel M, Hegde M, Girish YR, Byregowda TR, Rao S, Raghavan SC and Rangappa KS: Antiproliferative and tumor inhibitory studies of 2,3 disubstituted 4-thiazolidinone derivatives. Bioorg Med Chem Lett 25: 3616-3620, 2015

29. Wang S, Zhao Y, Zhu W, Liu Y, Guo K and Gong P: Synthesis and anticancer activity of Indolin-2-one derivatives bearing the 4-thiazolidinone moiety. Arch Pharm (Weinheim) 345: 73-80, 2012.

30. Joseph A, Shah CS, Kumar SS, Alex AT, Maliyakkal N, Moorkoth S and Mathew JE: Synthesis, in vitro anticancer and antioxidant activity of thiadiazole substituted thiazolidin-4-ones. Acta Pharm 63: 397-408, 2013

31. Ottanà $\mathrm{R}$, Carotti $\mathrm{S}$, Maccari $\mathrm{R}$, Landini $\mathrm{I}$, Chiricosta $\mathrm{G}$, Caciagli B, Vigorita MG and Mini E: In vitro antiproliferative activity against human colon cancer cell lines of representative 4-thiazolidinones. Part I. Bioorg Med Chem Lett 15: 3930-3933, 2005.

32. George RF: Stereoselective synthesis and QSAR study of cytotoxic 2-(4-oxo-thiazolidin-2-ylidene)-2-cyano-N-arylacetamides. Eur J Med Chem 47: 377-386, 2012.

33. Živković MB, Matić IZ, Rodić MV, Novaković IT, Krivokuća AM, Sladić DM and Krstić NM: Anticancer potential of new steroidal thiazolidin-4-one derivatives. Mechanisms of cytotoxic action and effects on angiogenesis in vitro. J Steroid Biochem Mol Biol 174: 72-85, 2017.

34. Suthar SK, Jaiswal V, Lohan S, Bansal S, Chaudhary A, Tiwari A, Alex AT and Joesph A: Novel quinolone substituted thiazolidin-4-ones as anti-inflammatory, anticancer agents: Design, synthesis and biological screening. Eur J Med Chem 63: 589-602, 2013.

35. Kunzler A, Neuenfeldt PD, das Neves AM, Pereira CM, Marques GH, Nascente PS, Fernandes MH, Hübner SO and Cunico W: Synthesis, antifungal and cytotoxic activities of 2-aryl-3-((piperidin-1-yl)ethyl)thiazolidinones. Eur J Med Chem 64: 74-80, 2013

36. Zou Y, Wang J, Leng X, Huang J, Xue W, Zhang J and Huang Y: The selective MEK1 inhibitor Selumetinib enhances the antitumor activity of everolimus against renal cell carcinoma in vitro and in vivo. Oncotarget 8: 20825-20833, 2017.

37. Wang Y, Xia C, Lun Z, Lv Y, Chen W and Li T: Crosstalk between p38 MAPK and caspase-9 regulates mitochondria-mediated apoptosis induced by tetra- $\alpha$-(4-carboxyphenoxy) phthalocyanine zinc photodynamic therapy in LoVo cells. Oncol Rep 39: 61-70, 2018 